\title{
Understanding Agricultural Liability: Livestock and Other Farm Animals
}

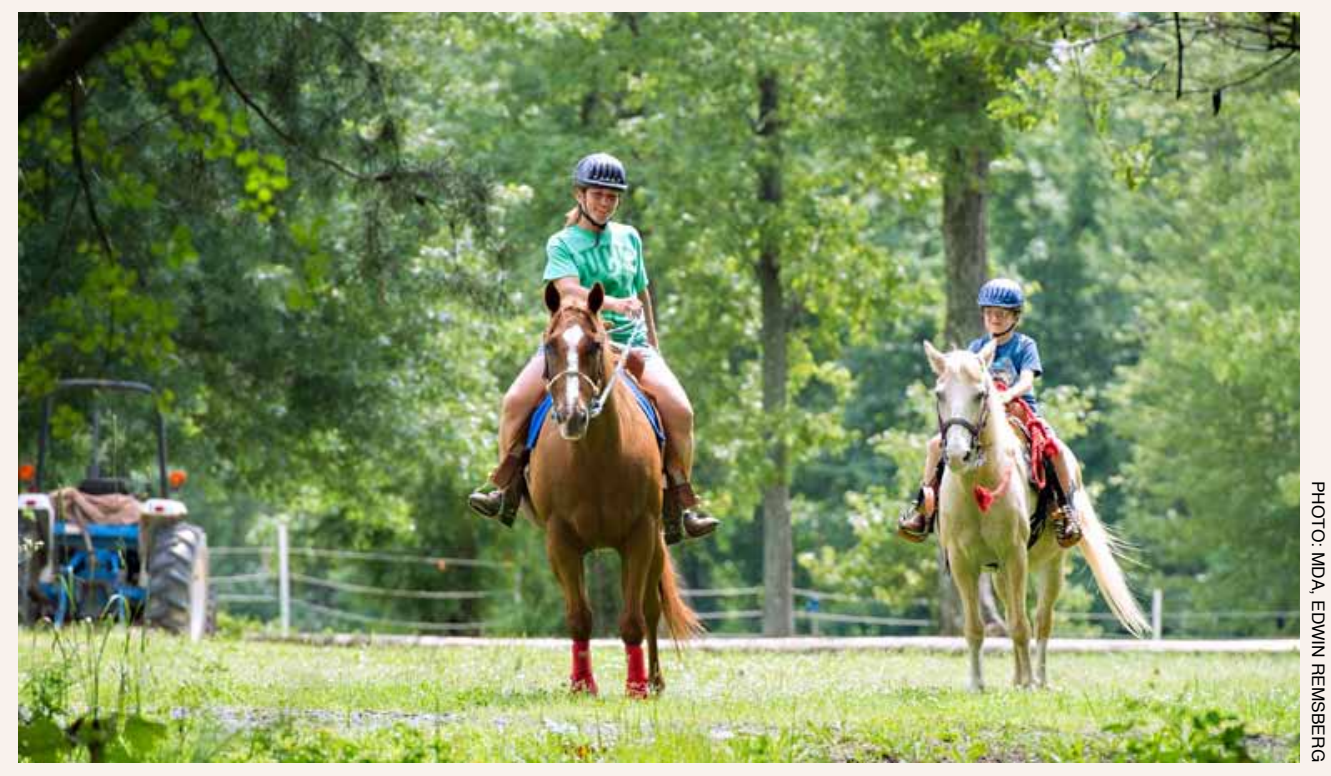

As a livestock owner, you need to understand the laws concerning liability for personal injuries caused by livestock in order to develop a risk management plan for your operation.

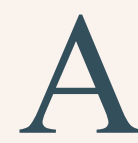
nimal agriculture carries certain potential legal risks for liability from injuries caused by livestock. A horse owned by a stable operator, for example, may throw or kick a rider. Cattle may injure a farm visitor. An ornery goat or ram might insist on giving anyone who enters the field a solid head butt, or an unfriendly goose might give chase.

You get the point. As a livestock owner, you need to understand the laws concerning liability for personal injuries caused by livestock in order to develop a risk management plan for your operation. This fact sheet contains the information you will need to understand the possible legal risks and develop strategies to limit potential liability.

Remember it is unlikely that you will be able to limit 100 percent of the legal risk you face in any facet of your agricultural operation. There are only tools available, such as insurance, hanging warning signs, or developing strategies for dealing with potentially dangerous livestock that can work to limit a portion of that liability.

This fact sheet does not cover liability issues associated with livestock that escape from a pasture or other confined areas. For more information on those situations, please see the Extension Bulletin, "Understanding Agricultural Liability: Maryland Fencing Laws," (FS-989). 
Maryland law provides two different theories of liability for personal injuries caused by domestic animals (Pahanish, 1986). Under the strict liability theory, liability is not centered on an animal owner being negligent or intentionally causing harm. Instead, liability stems from a breach of an absolute duty (Pahanish, 1986).

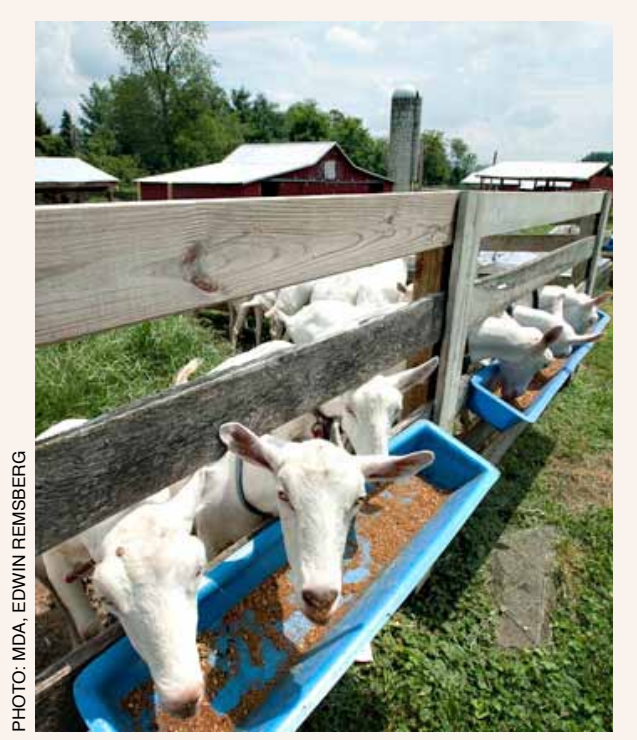

Stable operators or agritourism operators who allow people to come in contact with livestock owe a higher duty of care to protect their customers from unreasonable risks.

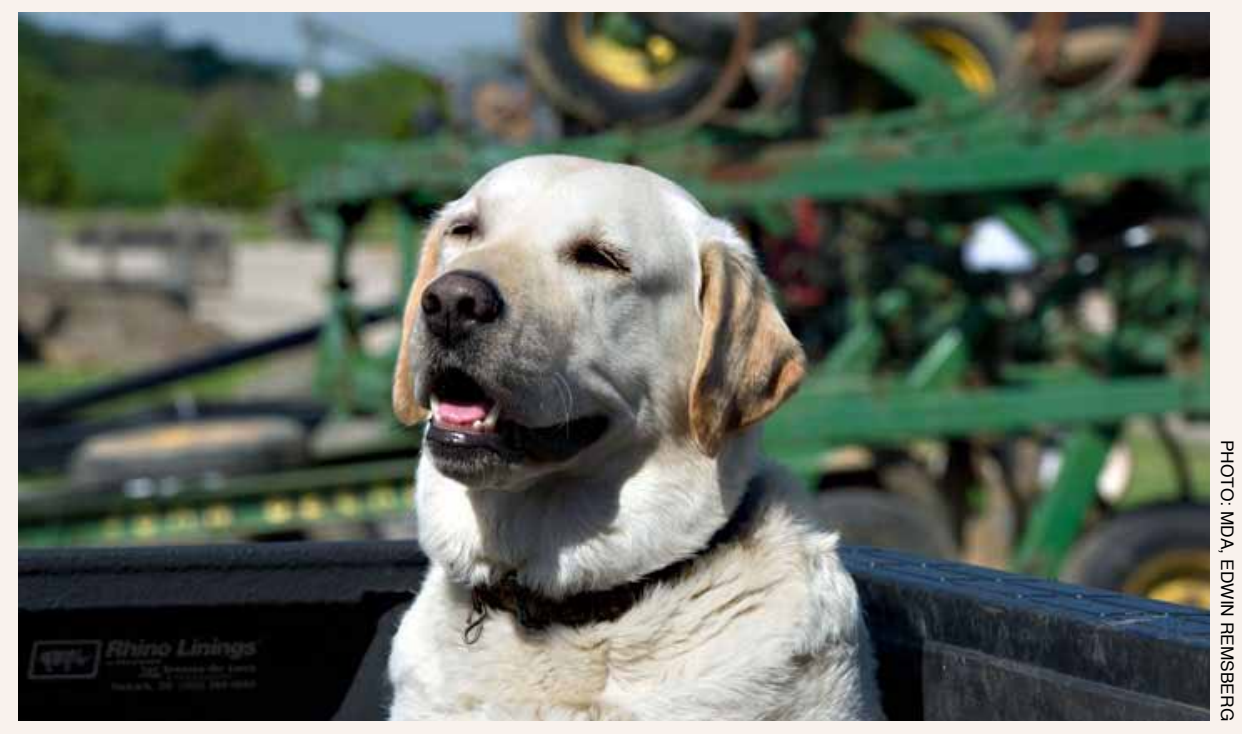

Domestic animals include livestock, such as cattle, sheep, horses, and goats, as well as pets, such as dogs and cats.

\section{Maryland Livestock Owners May be Liable for Personal Injuries Caused by Their Livestock}

Under Maryland law, the animal causing the injury must be a "domestic animal" (Briscoe, 1993), which is defined as any animal "domesticated so as to live and breed in a tame condition" (Merriam-Webster, 2013). Domestic animals include livestock, such as cattle, sheep, horses, and goats, as well as pets, such as dogs and cats. Domestic animals also may include buffalo, emu, deer, and other animals part of a farm operation, but as of publication of this article, the Maryland courts have not included such domestic animals under state liability law.

Maryland law provides two different theories of liability for personal injuries caused by domestic animals (Pahanish, 1986). Under the strict liability theory, liability is not centered on an animal owner being negligent or intentionally causing harm. Instead, liability stems from a breach of an absolute duty (Pahanish, 1986). In a recent controversial example, the Maryland Court of Appeals declared that owners of pit bull terriers were strictly liable for injuries caused by their dogs because the court determined that particular breed has a "well known propensity" for aggression.

Negligence liability (Pahanish, 1986) stems from the failure to provide the same standard of care as a reasonable person exercising average judgment, skill, and care in the identical situation. An injured party would have to show that you were "unaware of any mischievous propensity on the animal's part, if (you, as the owner of the animal) ... failed to exercise reasonable care in controlling the animal or preventing the harm caused by (the animal)" (Pahanish, 1986). This is sometimes referred to as a "reasonable and prudent person standard" (Black's Law Dictionary, 2004). For example, we expect a truck driver of average skill, judgment, and care to fasten down any loads on a flatbed trailer before going down the highway. If the truck driver forgets to tie down the load before leaving, he/she would be negligent. 


\section{Strict Liability Requires That Animal Has Caused Similar Injury or That Owner Knew of a Natural Tendency for Animal to Commit Injurious Act}

In one decision, the Maryland Court of Appeals found that a stable owner was negligent when his dog was growling and barking behind a usually gentle horse. The horse bolted, throwing and injuring the child rider. The Court of Appeals based its decision on the fact that the stable owner's dog had a history of frightening horses (Herbert, 1958).

Another example would be if you know that your bull has destroyed a fence to chase individuals near its pen because the bull has chased you. One day, your neighbor is helping you separate cattle and the bull climbs the fence, charges, and severely injures your neighbor. You could be found strictly liable for your neighbor's injuries. You would not be liable, however, if the bull had never chased anyone and your neighbor's injuries were the first time the bull had caused harm.

\section{Negligence Requires Injured Person to Show that Owner Failed to Exercise Effective Control When It's Reasonably Expected Injury Could Occur}

Let's assume that you operate a riding stable and take clients out for trail rides. You take a family and an old college friend out for a ride and you spend more time chatting with your friend than paying attention to the family. One of the horses being ridden by a member of the family rears up and lunges. Since you are leading the ride, you don't see what's happening until you hear a child scream: the horse threw the daughter and she has a broken arm. Based on the limited facts, this could be a case where you acted

\section{Outcomes in negligence}

cases will depend on the individual facts in each case. negligently. If the family were all first-time riders, we would expect a reasonable person to pay close attention to the family, especially the children, and to not be distracted by talking with an old friend.

In contrast, if the family were older and experienced riders, we may not expect a reasonable person to be as attentive to the family. Outcomes in negligence cases will depend on the individual facts in each case. Previous cases may not always be an indicator of the situation or outcome in your individual case.

Negligence requires the animal owner to have a duty of care towards the injured party. "Duty of care" is the legal obligation you owe to an individual to protect them from foreseeable harm. The duty of care owed the injured party will depend on whether the injured was a trespasser, licensee, or invitee.

A trespasser is owed the lowest duty of care - the owner should refrain from wanton and willful injury to the trespasser. An invitee will be owed the highest duty of care - protection from unreasonable risks. Stable operators or agritourism operators who allow people to come in contact with livestock owe a higher duty of care to protect their customers from unreasonable risks.

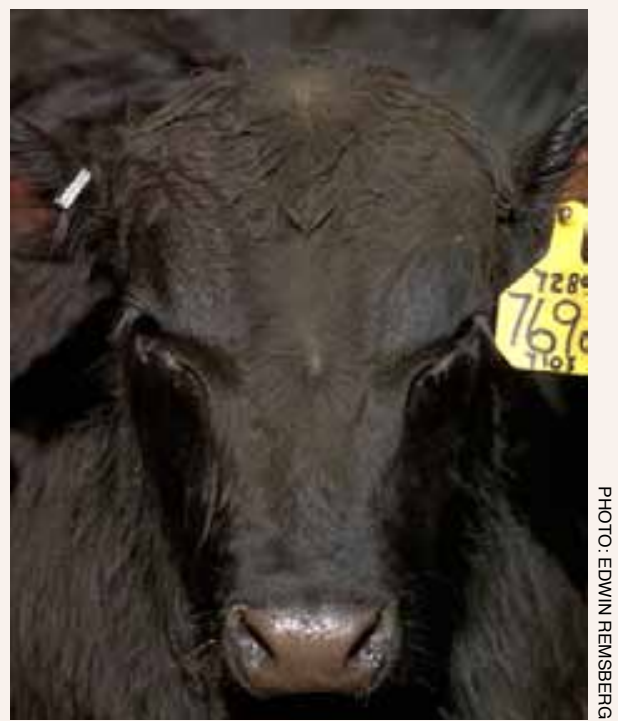

An owner could be found liable if aware of an animal's natural tendency to commit an injurious act. 


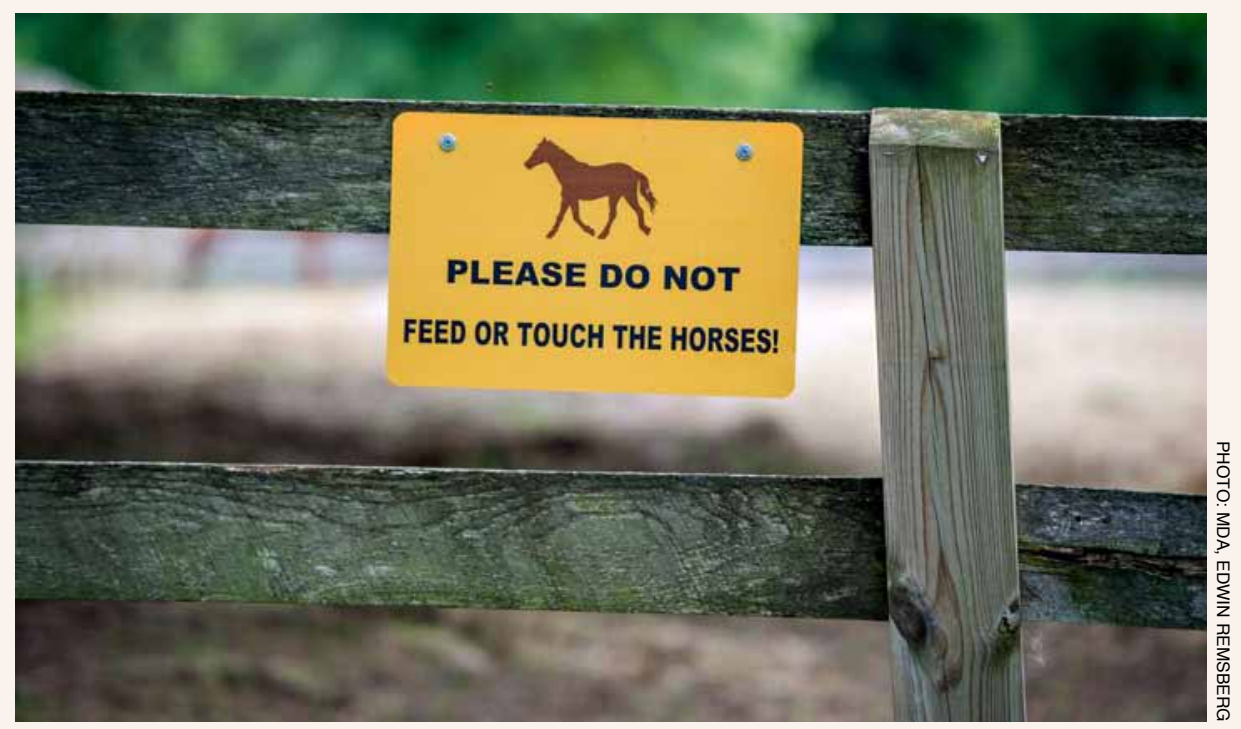

One strategy to consider is hanging warning signs in places visible to visitors.

For more information on status and the duty of care owed to them, see Extension Fact Sheet "Understanding Agricultural Liability: Premise Liabilities."

\section{Managing Your Risks Requires Assessment of Livestock's Past Actions}

As you develop your liability management plan, consider working with an attorney and an insurance agent to develop strategies to limit any potential liability from livestock. The first step in determining strategies is to consider whether any of your livestock has a history of acting in ways that could injury someone. Do you own cows or bulls that have chased you, your employees, or others? For stable owners, has a horse thrown a rider, kicked or bitten a person, or done other things which could cause injury?

Next consider how likely it is for your livestock to come in contact with third parties, such as trail ride customers or passersby. Considering your legal risk management options allows you to implement strategies before an injury occurs.

Strategies may include providing notice of livestock on the property by hanging warning signs on fences or making sure you have the proper insurance coverage. In some cases, your attorney may be able to provide you with a form that your clients or visitors can sign which releases you in advance for injuries that your livestock may cause.

Note: This publication is intended to provide general information in understanding some aspects of liability that may be associated with livestock and is not intended to provide legal advice. It should not be cited or relied upon as legal authority. State laws vary and no attempt is made to discuss laws of states other than Maryland. For advice about how the issues discussed here might apply to your individual situation, you should consult an attorney. 


\section{References}

Briscoe v. Graybeal, 622 A.2d 805 (Md. Ct. Spec. App. 1993).

Garner, Bryan A., ed. 2004. Black's Law Dictionary, 8th ed. St. Paul:

Thomson West.

Goeringer, L. Paul. 2014. "Understanding Agricultural Liability: Maryland Fencing Laws.” Agricultural Law Fact Sheet (FS-989).

Goeringer, L. Paul and Lori Lynch. 2014. "Understanding Agricultural Liability: Premise Liability.” Agricultural Law Fact Sheet (FS-988).

Herbert v. Ziegler, 139 A.2d 699 (Md. 1958)

Pahanish v. Western Trails, Inc., 69 Md. App. 342 (1986).

\section{This publication is offered in a partnership with:}

U N I V E R S I T Y OF

MARYLAND

E X T E N S O N

Solutions in your community

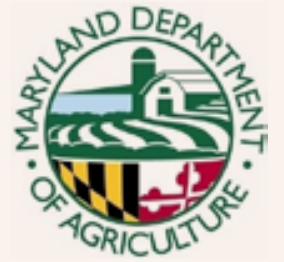

\section{USDA}

United States Department of Agriculture Risk Management Agency
Authored by:

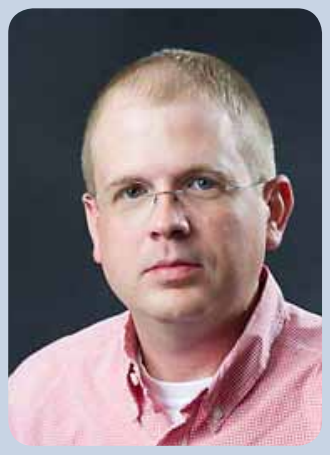

Paul Goeringer Extension Legal Specialist

In accordance with Federal law and U.S. Department of Agriculture policy, this institution is prohibited from discriminating on the basis of race, color, national origin, sex, age, or disability. To file a complaint of discrimination, contact USDA, Office of the Assistant Secretary of Civil Rights, Whitten Building, 1400 Independence Ave., SW., Washington, D.C., 02050-9410 or call 1-866-632-9992 Toll Free; or 1-800-877-8339 Federal Relay Service; or 1-800-845-6136 (In Spanish); or 1-800 795-3272 between the hours of 8:30 am and 5:00 pm Eastern Standard Time; or (TDD) 720-2600. USDA is an equal opportunity provider and employer.

The Agriculture Law Education Initiative is a collaboration between the University of Maryland Francis King Carey School and College of Agriculture \& Natural Resources, University of Maryland, College Park. Through the University of Maryland Extension - the statewide, non-formal agriculture education system the collaboration partners with the School of Agricultural and Natural Sciences, University of Maryland Eastern Shore.

The University of Maryland: MPowering the State brings together two universities of distinction to form a new collaborative partnership. Harnessing the resources of each, the University of Maryland, College Park and the University of Maryland, Baltimore will focus the collective expertise on critical statewide issues of public health, biomedical informatics, and bioengineering. This collaboration will drive an even greater impact on the state, its economy, the job market, and the next generation of innovators. The joint initiatives will have a profound effect on productivity, the economy, and the very fabric of higher education.

University of Maryland College of Agriculture and Natural Resources

Department of Agricultural and Resource Economics

Symons Hall, Room 2119

College Park, MD 20742

www.umaglaw.org

Twitter @MDAgLaw

(301) 405-1293 